\title{
Changes in hemopoietic tissue of rainbow trout under influence of stress
}

\author{
Gabriele Peters \& Rolf Schwarzer
}

Institut für Hydrobiologie und Fischereiwissenschaft der Universität Hamburg, Olbersweg 24, D-2000 Hamburg 50, Federal Republic of Germany

\begin{abstract}
As in higher vertebrates, stress increases the susceptibility of fishes to disease. This effect is accompanied by changes in circulating white blood cells: the number of lymphocytes decreases while the number of granulocytes increases. Investigations were therefore undertaken to determine in what ways stress induces changes in hemopoietic organs, particularly spleen and head kidneys of rainbow trout Salmo gairdneri. Handling and social conflict were used as stressors. These psychic stimuli are typically encountered in aquaculture and under laboratory conditions. Under the influence of both stressors hemopoiesis in spleen and head kidney is disturbed. Blast cells become rare or disappear completely from the tissue. The numbers of mature, intact PMN cells and of small lymphocytes also decrease. Hypertrophic macrophage-like cells with vacuolized cytoplasm appear in increasing numbers. They develop mainly from immature PMN and reticuloendothelial cells. They swell continuously while undergoing evident disintegration. At the same time, destruction of erythrocytes proceeds at an increased rate. The high numbers of macrophage-like cells may indicate that the stressors initially stimulate the defense mechanisms and thereby serve an adaptive function. Possibly. under continued stress, their proteolytic enzymes begin to damage the body's own blood cells. The decreased production of new blood cells and the increased destruction of immune-competent cells still present seem finally to contribute to disease susceptibility under stress.
\end{abstract}

\section{INTRODUCTION}

In vertebrates, stress causes multiple changes in the hormone balance; these are characterized especially by activation of the hypothalamus-hypophysis-adrenal system. According to Selye (1936), this serves to return the body to the original condition of homeostasis. Such an adaptation attempt, marked by mobilization of energy reserves, is accompanied by numerous secondary effects, including a significantly increased susceptibility to disease (Wedemeyer 1970, Snieszko 1974). This shows that endocrine changes also affect the immune system; the causal relations involved seem to be very complex (Ellis 1981).

Undoubtedly, the lymphoid system plays a major role in the attempt of an organism to resist a stressor or to adapt to it. The elements of this system are capable of employing different defence mechanisms - such as phagocytosis of invading pathogens, their destruction by antibodies, and their lysis by chemical agents.

It has been observed repeatedly that the influence of stress manifests itself by typical, but non-specific, changes in white blood cells. The changes include particularly the increased abundance of neutrophilic granulocytes and the reduced numbers of lymphocytes. According to Slicher et al. (1962), cold shock or ACTH application can induce such changes in killifish Fundulus heteroclitus. Trout also react to various stressors by developing lymphocytopenia and heterophilia (Weinreb 1958, Pickford et al. 1971, McLeay 1973).

Psychic stress, such as that caused by conflicts to establish social rank, can also cause changes in numerical relations of the various white blood cell types in eels (Peters et al. 1980, Hong 1982, Klinger 1983).

Information about the fate of white blood cells, i. e. their origin and elimination in the body under the influence of stress, is confined almost exclusively to suppositions based on findings on mammals, in which lymphatic tissue atrophies under stress (Selye 1976), lymphocyte numbers in the hemopoietic tissues decrease, granulopoietic processes in the bone marrow are suppressed, and lysis of the lymphocytes occurs (Dougherty 1952). In order to obtain more information on the relation between stress and immunological defense of fish, cytological changes in organs of blood formation and blood-cell elimination were investi- 
gated. In the young rainbow trout examined, these functions are performed primarily by spleen and head kidney. The tissues of these organs were examined as smears and sections. Stress was produced by battles for rank and by handling. In this way, situations were simulated to which fish can be exposed in captivity, particularly under artificial conditions prevailing in aquaculture systems or under laboratory conditions.

\section{MATERIAL AND METHODS}

Rainbow trout Salmo gairdneri fingerlings, 10 to 20 $\mathrm{cm} \mathrm{TL}$, were kept in square, 201 containers (flowthrough system). Except for a drain pipc, about $25 \mathrm{~cm}$ high, no objects were present to offer the fish a hiding place. Water temperature was $11^{\circ} \mathrm{C} \pm 2 \mathrm{C}^{\circ}$. The daily food ration offered to the fish equalled $4 \%$ of their total weight.

Social stress was produced by placing 2 individuals in 1 container in which it was impossible for them to avoid confrontation ( $\mathrm{n}=28$ ). In such situations, battles for dominance occur, and the loser becomes exposed to psychic stress (Peters et al. 1980). Tests were discontinued either after $24 \mathrm{~h}$ (short-term stress $=$ ss) or later, after the subordinate indivual showed clear signs of exhaustion (long-term stress $=1$ s), a condition that was noted as early as $3 \mathrm{~d}$ and as late as $30 \mathrm{~d}$ after starting the experiment. Fish kept alone served as controls $(\mathrm{n}=11)$.

Handling stress was produced by capturing and removing fish kept alone once each day $(n=9)$. The fish were carried in a hand net to a 51 pail and after $10 \mathrm{~s}$ returned to the container. Food was provided $11 / 2 \mathrm{~h}$ after handling. The experiment lasted $4 \mathrm{wk}$.

Growth rate of the fish was determined by weighing each individual in a known quantity of water every $8 \mathrm{~d}$.

Changes in the structure of organs were determined by examining tissue smears. Fresh pieces of tissue from anaesthetized fish were teased apart on fat-free slides and then smeared. After being air dried for $24 \mathrm{~h}$, smears were stained with May-Grünwald-Giemsa. In several visual fields at $1000 \times$, all blood cells were identified, counted, and their relative abundance determined. From each fish, 250 to 500 blood cells were included in the counts

Tissue samples were fixed in Bouin's fluid, embedded in paraffin, cut into $5 \mu \mathrm{m}$ sections, and stained with HE. Specimens for EM examination were fixed in glutaraldehyde and stained with osmium tetroxide.

Observations on behavior were made for periods of $1 / 2 \mathrm{~h}$ during the first hour after the start of the experiment, $24 \mathrm{~h}$ later, after each handling procedure, and during feeding.

\section{RESULTS}

\section{Behavior of the fish}

Social stress

Among the majority of fish pairs kept together, vehement dominance battles began within 20 min after starting the experiment. Usually the larger and stronger fish $(\alpha)$ pursued the subordinate partner $(\beta)$, aggressively biting it, usually in the tail region. As many as 14 attacks min $^{-1}$ were observed, and there were usually no counterattacks. During conflict, the color of the $\alpha$ fishes became lighter.

About $1 \mathrm{~h}$ after beginning the experiment, the number of attacks usually decreased significantly. By this time, dominance was established. The a fish swam freely around the container, while the $\beta$ fish remained in one of the corners with its body bent unnaturally. This behavior generally continued for the remainder of the experiment.

During feeding, the hierarchy became less strict for a short time, and both fish consumed food. Nevertheless, the subordinate fish began to appear undernourished after a few days. Some of them displayed fraying and clouding of the caudal fin, from which a necrosis began to spread anteriorly until the entire caudal peduncle was affected. Fish with this condition died within a few days. Between some of the experimental pairs (about $1 / 3)$, aggressive conflicts did not break out. Nevertheless, dominance was established within $24 \mathrm{~h}$; the $\beta$ fish responded with a behavior indicating fear and deterioration of its physical condition occurred.

\section{Handling stress}

After handling, trout darted rapidly about for $5 \mathrm{~s}$, then remained in an unnaturally curled up position in one of the corners for another 15 to $30 \mathrm{~s}$. After $5 \mathrm{~min}$, they behaved like the controls, i. e. remained in the center of the container, calm and breathing at a steady rate and exhibiting a normal coloration. No injuries or infections were noted. The conditions of the fish remained good throughout the experiments.

\section{Growth}

\section{Social stress}

Growth of both control fish kept alone and dominant fish $(\alpha)$ was equally good. Among all experimental pairs, growth of $\beta$ fishes was significantly slower than that of unstressed individuals (Fig. 1). On average, 


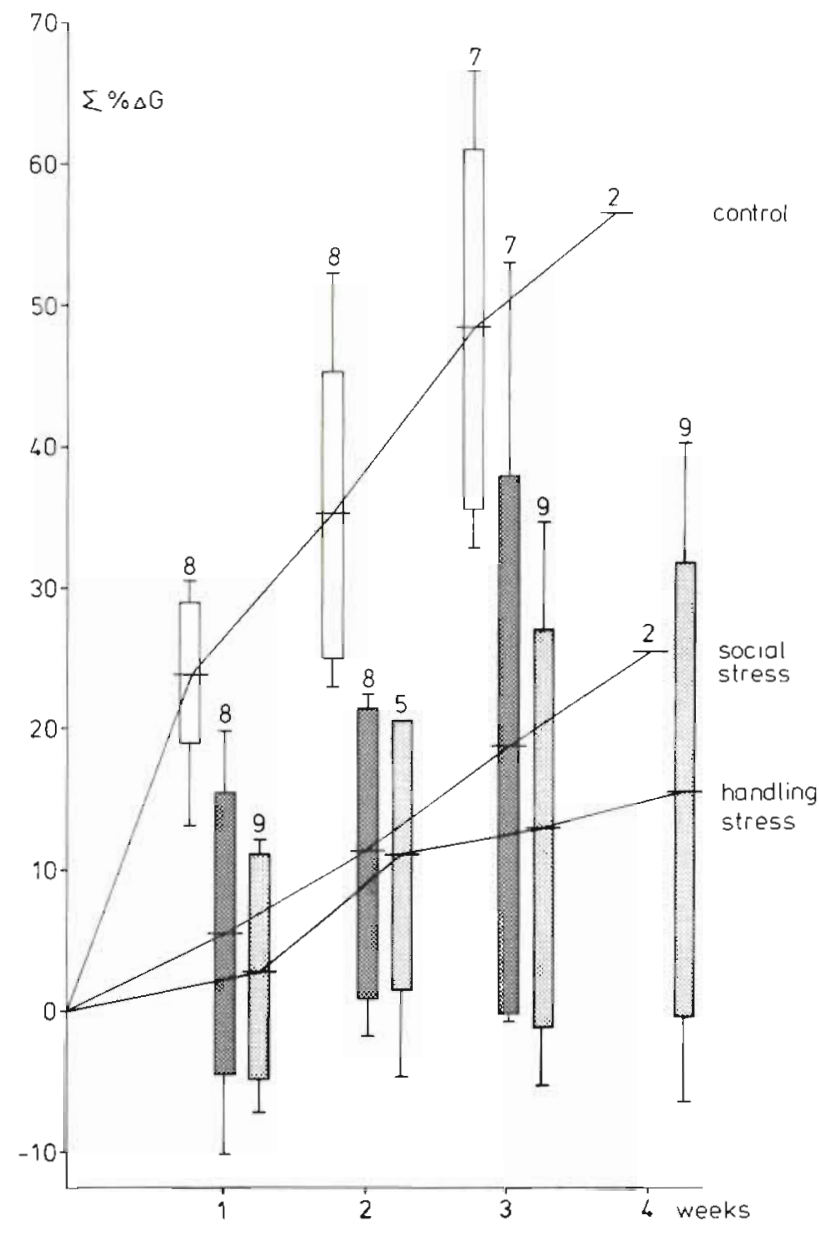

Fig. 1. Salmo gairdneri. Growth of unstressed trout (control) and those under stress from handling or social conflict, depicted as cumulative percentage of original size. Horizontal line $=$ mean $(\bar{x})$, bars $= \pm S D$; vertical line $=$ total range; above, number of individuals ( $\mathrm{n}$ )

growth of the stressed fish was about $1 / 3$ that of its partner. This difference remained the same for the duration of experiments. Some stressed fish lost weight. The situation was the same whether the dominant partner was aggressive or remained passive.

\section{Handling stress}

In all handling experiments, the fish grew slower than in the controls (Fig. 1). In a few cases weight losses were also recorded.

\section{Hemopoietic tissue of spleen and head kidney \\ Characteristics of blood cells}

In spleen and head kidney smears, 8 cell types can easily be identified and counted (Fig. 2\&7). In the following morphological description they are listed together with synonyms used by other authors (Finn \& Nielson 1971, Anderson 1974, Lehmann \& Stürenberg 1975, Ellis 1977, Klinger 1983):

Hemoblast. Large, round cell in which the basophilic cytoplasm forms a narrow band around the large, round nucleus. Sometimes the nucleus has an eccentric position, sometimes it is placed more symmetrically. The chromatin forms a loose, irregular network. The nucleus fills 80 to $90 \%$ of the cell volume. ( Granuloblast, stem cell, proerythroblast, large blast cell.)

Erythroblast. Round or slightly ovoid cell with basophilic cytoplasm and round or slightly ovoid nucleus, which contains a diffuse chromatin of varying density and fills 40 to $60 \%$ of the cell volume. ( Erythroblast I and II, polychromatic erythrocyte, small blast cell, proerythrocyte.)

Pro-PMN-cell. Round to oval cell with slightly basophilic cytoplasm and large, bean-shaped nucleus eccentrically placed. The nucleus occupies 50 to $70 \%$ of the cell volume. ( Progranulocyte, metagranulocyte.)

Erythrocyte. Oval cell with oval nucleus. The structure of the chromatin varies with the degree of maturity.

Lymphocyte. Small round cell with strongly basophilic cytoplasm. The large round nucleus is centrally located and slightly indented. The structure of the chromatin is dense and lumpy. The nucleus occupies ca $85 \%$ of the cell volume.

PMN-cell. Round cell with curving sausage-shaped, indented or segmented nucleus clearly delimited from the cytoplasm. The homogeneous cytoplasm is neutrophilic or slightly basophilic and contains no visible granules. The nucleus occupies 30 to $40 \%$ of the cell volume. ( Polymorphonuclear cell, neutrophil, segmentkerniger Granulozyt, stabkerniger Granulozyt.)

Atypical erythrocyte. Erythrocytes and erythroblasts in various stages of deformation showing great structural and chromaffinic variability. As the degeneration progresses, the nucleus and cytoplasm deteriorate to a 'red spot' (these were not counted because they can be formed by bursting during the preparation of the slides).

Macrophage-like cell. Large, polymorphic cells with polymorphic nuclei. Both the cytoplasm and the karyoplasm stain weakly and contain many vacuoles. In some of them phagocytized inclusions or pigments are evident. ( Macrophage, sinusoidal cell, stress lymphoid, monocytoid, Lymphoretikuläre, immunoblast.)

Basophilic granulocytes, monocytes, thrombocytes, and plasma cells were not counted because of their scarcity. 

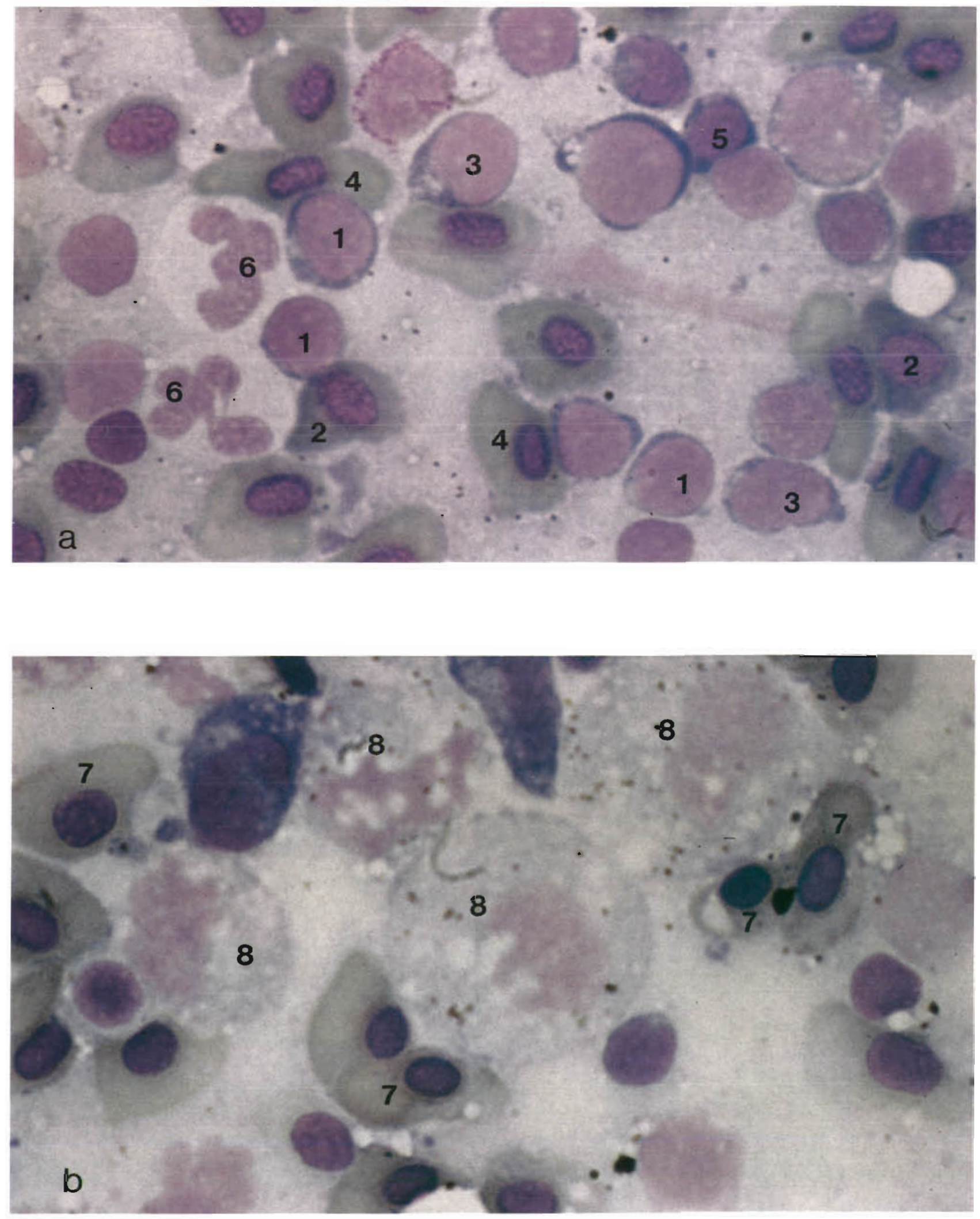

Fig. 2. Salmo gairdneri. Smears of rainbow trout spleen tissue. (a) Dominant fish; (b) its subordinate partner after $3 \mathrm{~d}$ of experiment. $1=$ hemoblast, $2=$ erythroblast, $3=$ pro-PMN-cell, $4=$ erythrocyte, $5=$ lymphocyte, $6=$ PMN-cell, $7=$ atypical erythrocyte, 8 = macrophage-like cell. Stained with May-Grünwald-Giemsa 
Changes in the spleen

\section{Structural changes}

Alterations in both white and red blood cells in the hemopoietic tissue of the spleen occur under the influence of stress (Fig. 2b). Hemoblasts, pro-PMN- and PMN-cells usually show effects that are, in principle, similar. The normally compact cells swell to several times their normal volume. The hypertrophy is chiefly attributable to multiple vacuolation that makes the cytoplasm appear foamy. The cells take on the form of macrophages and are thereafter referred to as macrophage-like cells.

Early stages still show typical characteristics of the precursor cell. Thus, the hemoblasts and pro-PMN cells undergoing hypertrophy display their large, round or crescent-shaped nuclei in the vacuolated
Fig. 3. Salmo gairdneri. Smear of splenic tissue from a subordinate rainbow trout. Clusters of erythrocytes surround macrophage-like cells. Stained with May-Grünwald-Giemsa

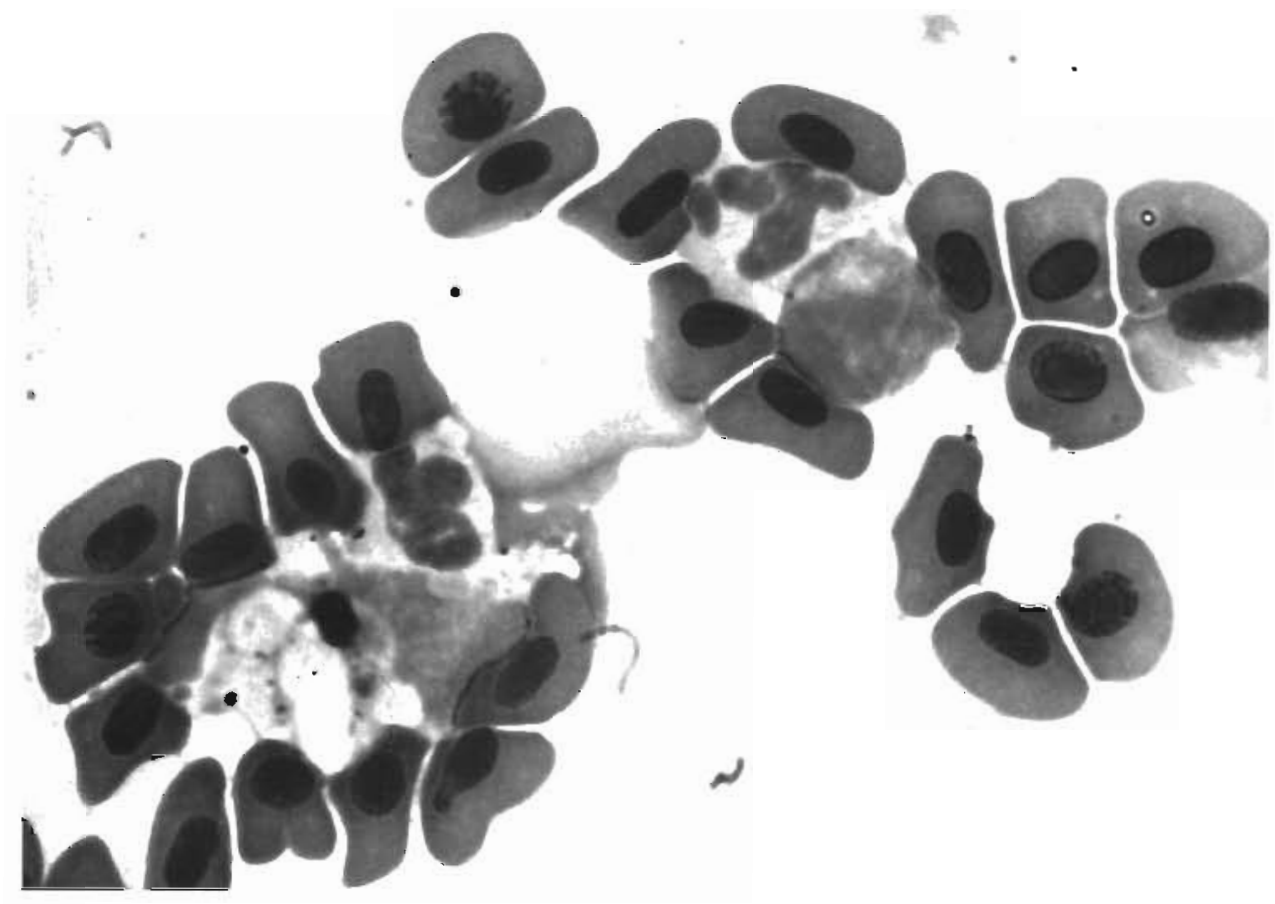

Fig. 4. Paraffin section of splenic tissue from a subordinate trout. Short anows $=$ hypertrophic RES-cells; long arrows $=$ hypertrophic PMN cells, $\mathrm{x}=$ edematous space. Stained with $\mathrm{HE}$

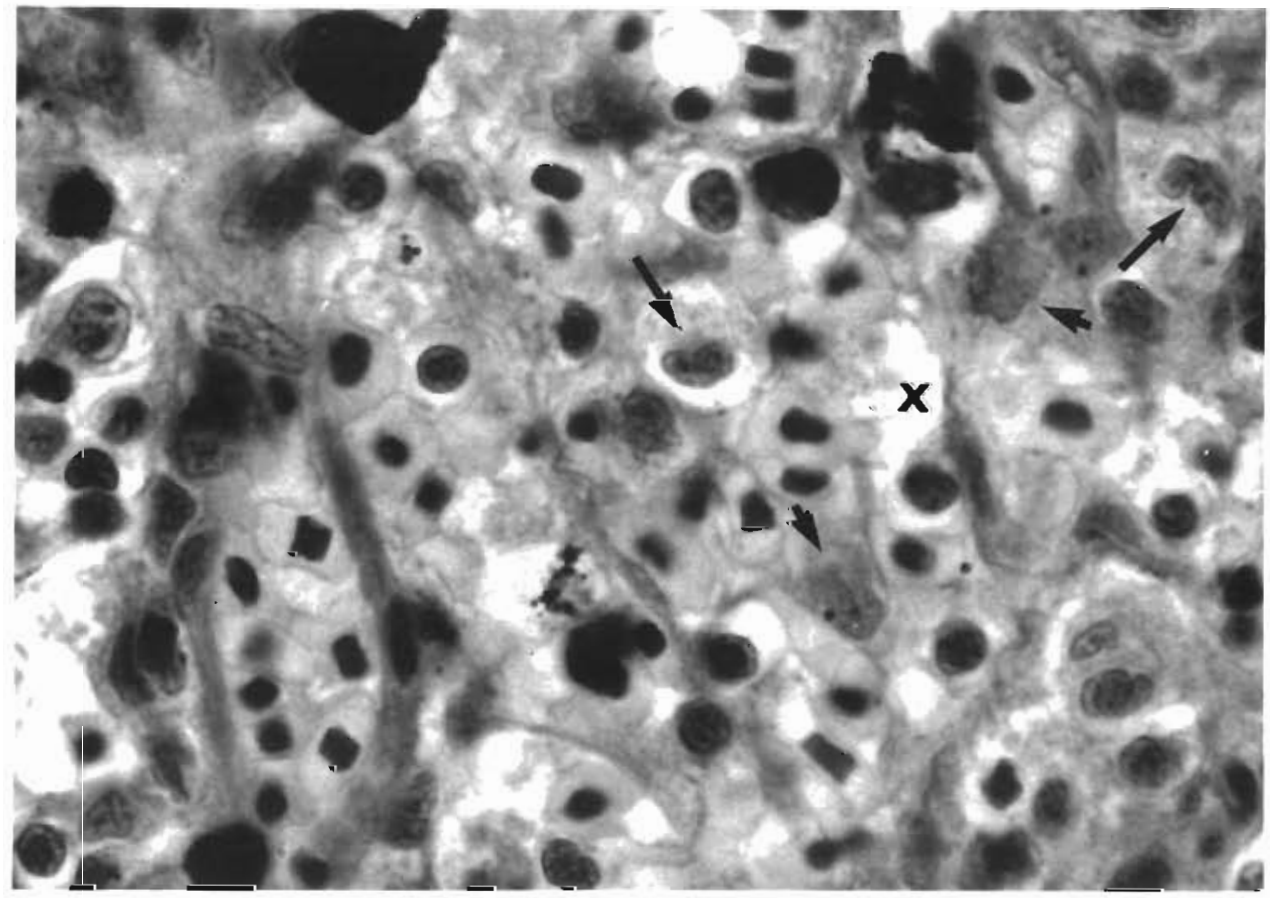


cytoplasm, which has lost some of its affinity for stains. Segmented nuclei are also recognizable in mature granulocytes that are beginning to swell, but their outlines are becoming less definite, and the karyoplasm seems less dense. As the swelling increases, the cells assume a more and more irregular shape. The plasma becomes paler and finally the whole cell is visible only as an outline. Lymphocytes and many of the hemoblasts frequently form pseudopodia, the surfaces of which disintegrate.

Under the condition of stress, many of the red blood cells also change their appearance. Unlike the leucocytes, however, these cells become smaller, and parts of them seem to be disintegrating. They are designated as atypical erythrocytes. In smears, erythrocyte aggregations surrounding macrophage-like cells are often

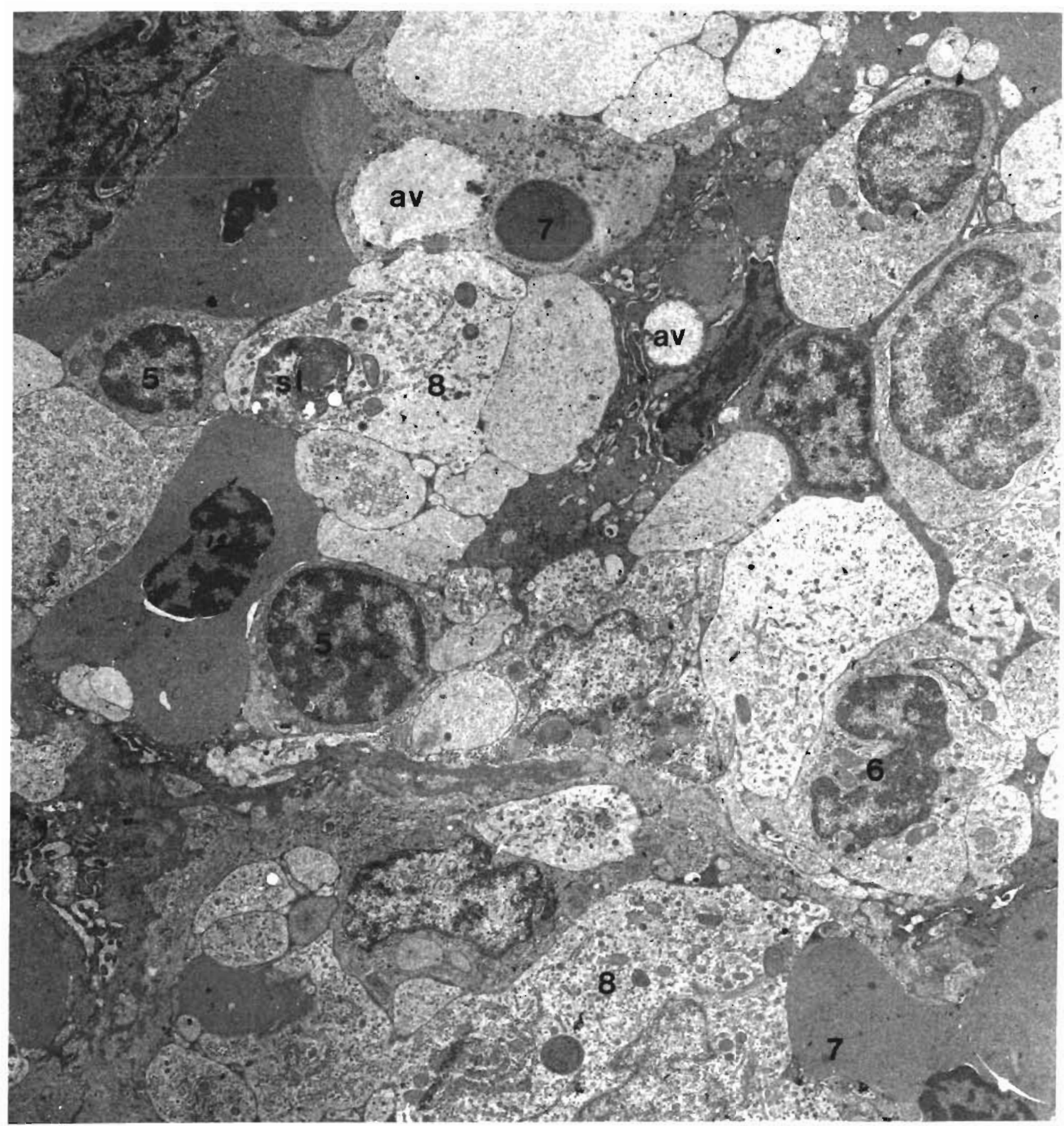

Fig. 5. Salmo gairdneri. EM of the spleen of a rainbow trout under social stress. av $=$ autophage vacuole, sl $=$ secondary lysosome. For key to numbers, see Fig. 2 
found (Fig. 3). The disintegration is particularly noticeable here.

In paraffin sections it is obvious that cells of the RES and capillary endothelia cells become hypertrophic as well. Sometimes edematous spaces develop in the tissue (Fig. 4). Electronmicrographs show that the white blood cells and the RES-cells enlarge by swelling of their pseudopod-like processes that spread between and around other tissue and blood cells (Fig. 5). By surrounding cells or parts of them they seem to phagocytize them. Remains of organelles and cytoplasm are encorporated in secondary lysosomes. Finally residual bodies are formed. The presence of autophage vacuoles shows that some of these cells may simultaneously cause self-destruction.

\section{Quantitative changes}

The effects of stress are manifested also by changes of the quantitative composition of the blood in the hemopoietic tissue (Fig. 6). The relative numbers of immature cells show a decreasing trend. This is obvious already within the first 24 hours (ss). If the stress continues (ls), the trend becomes stronger, until only about $1 / 5$ of them are left.

While the percentage of mature intact erythrocytes hardly changes under the influence of stress, that of intact white cells is reduced. Lymphocytes and PMNcells decrease so that after a long period of social stress, only $1 / 4$ of the original number remain.

Under the kind of stress in our experiments, the number of atypical cell elements increases considerably. The percentage of atypical erythrocytes rises from 0.5 to $20 \%$, the number of macrophage-like cells from $\sim 6$ to $18 \%$.

Stress from battles for rank and handling showed similar effects. When handling was continued for a longer period, however, there was a recovery in the hemoblast production.

\section{Changes in the head kidney}

The hemopoietic tissue in the head kidney of unstressed trout of stocking size bears a considerable resemblance cytomorphologically to the spleen (Fig. 7). The percentages of the blood cell types also resemble those found in the spleen (Fig. 8). Only the atypical erythrocytes are more abundant in the normal head kidney tissue than in the spleen.

The head kidney and spleen also show a great similarity in the symptoms that appear after social stress: the numbers of intact white blood cells decrease and the abundance of atypical erythrocytes and mac-
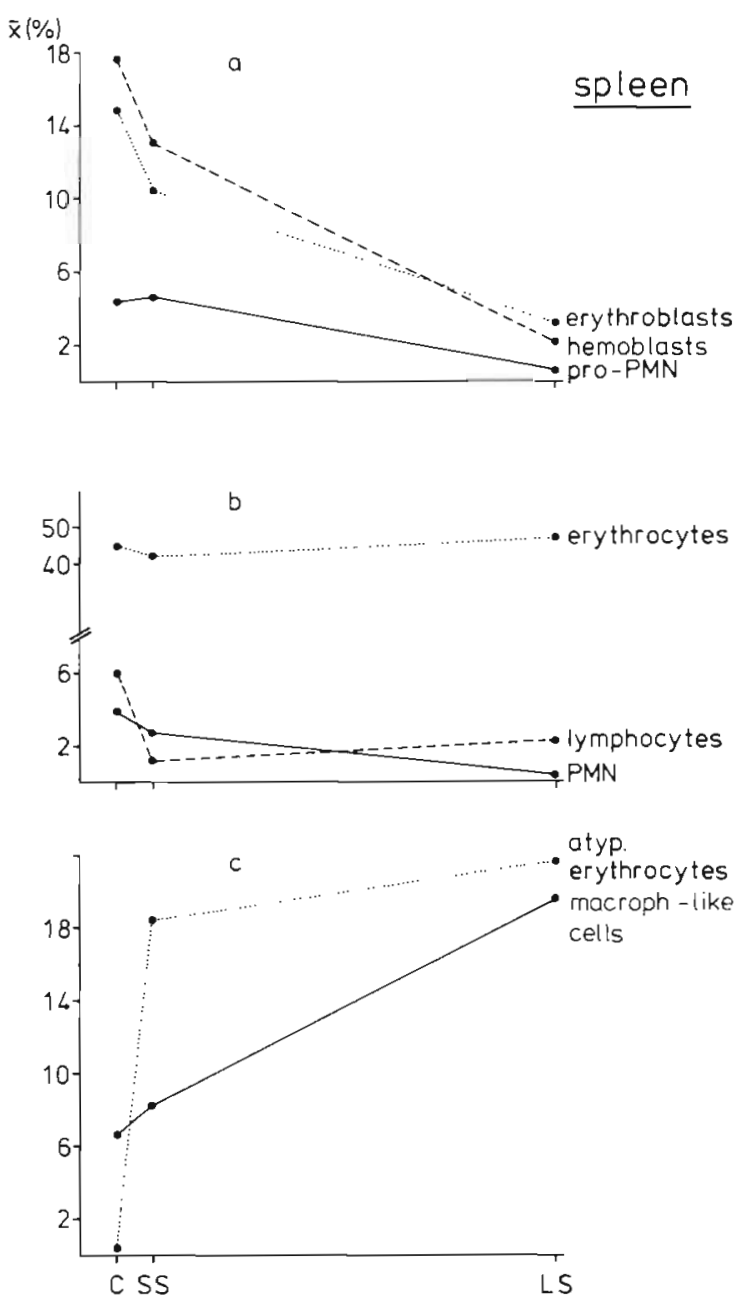

Fig. 6. Salmo gairdneri. Blood cell counts in spleen smears. (C) Start of experiment, (SS) after $24 \mathrm{~h}$. (LS) after several days of social stress. Each dot represents the mean percentage of cell counts from 6 fish

rophage-like cells increases. The changes are less pronounced, however. The number of blast cells drops shortly after the onset of stress. Later it returns to normal, while in the spleen it does not.

Handling, in the way we practised it, induces changes in the head kidney that are, in principle, the same as those caused by social stress, but the effects are less evident.

\section{DISCUSSION}

The main result of this investigation is that stress induces cellular changes in the hemopoietic tissues of the spleen and head kidney in the rainbow trout. The most prominent effects are an increase in the abundance of macrophage-like cells, a reduction in the numbers of hemoblasts and lymphocytes, and an enhanced red blood cell degradation. 


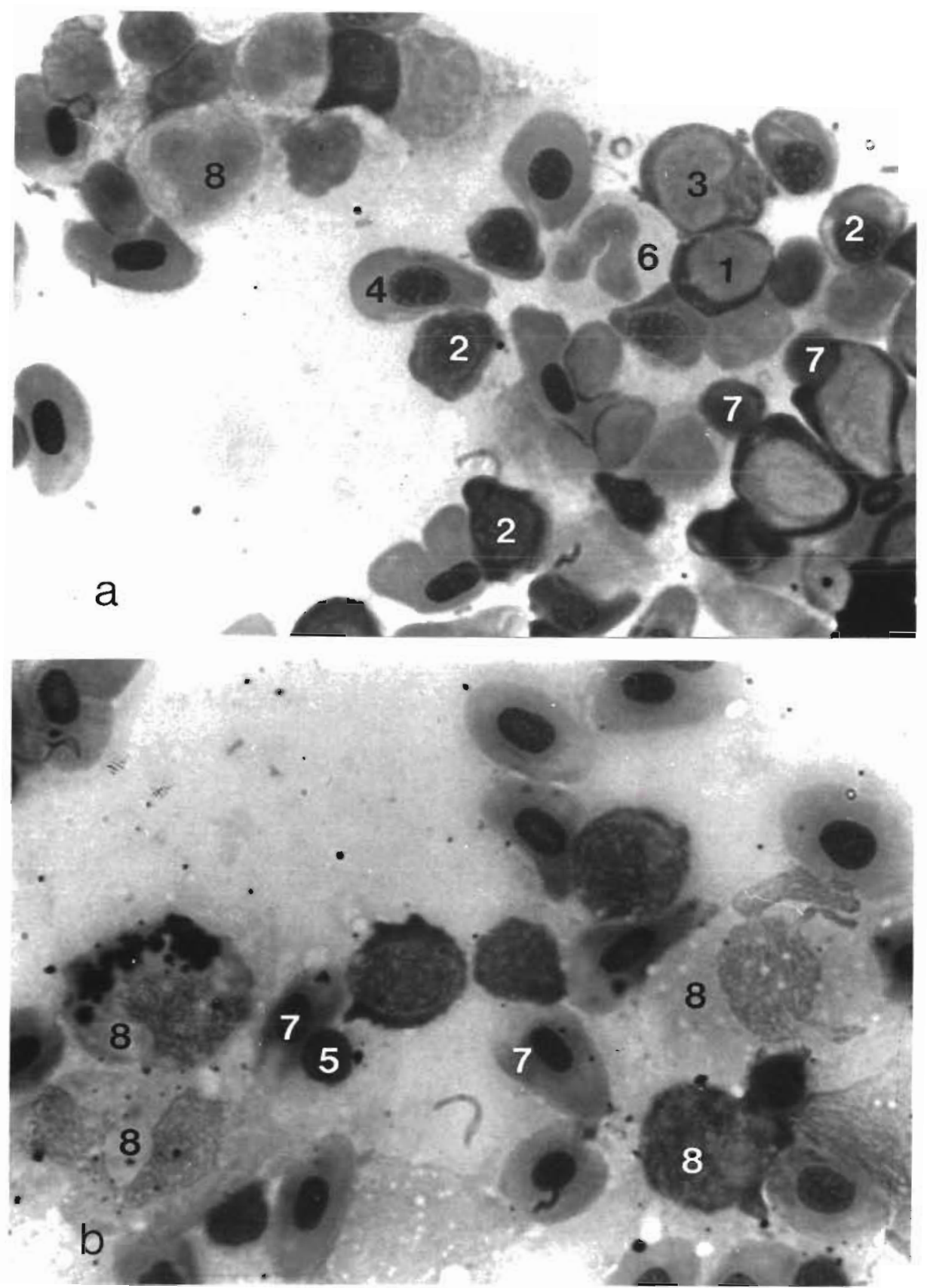

Fig. 7. Salmo gairdneri. Smears of head kidney tissue from rainbow trout. (a) Dominant fish; (b) its subordinate partner after $3 \mathrm{~d}$ of experiment. Stained with MayGrünwald-Giemsa. For key to numbers, see Fig. 2
Leucocytes are referred to as macrophage-like cells if they undergo hypertrophic processes whereby they gain the appearance of macrophages. Such alterations also occur in RES- and capillary endothelial cells. The macrophage-like cells seem to have hetero- and autophagocytotic capabilities. In EM-preparations, they are often seem to contain remains of organelles in various stages of degeneration. Finally degraded heterophagocytized material as well as autolysosomal vacuoles develop into residual bodies.

The process of deterioration can also be observed in normal spleen and head kidney tissues since it plays a role in the elimination of senescent erythrocytes, dead cells and antigen-antibody-aggregations. These processes generally take place through the activities of macrophages and reticuloendothelial cells (David 1970, Corbel 1975, Ingram 1980). They seem to be strongly stimulated by stress.

The disappearance of the blast stages from the hemopoietic tissue may be due to their transformation directly into the so-called atypical stages. In fact, among the atypical erythrocytes and macrophage-like cells there was always a large percentage with unmistakable characteristics of blast cells. The blastopenia 


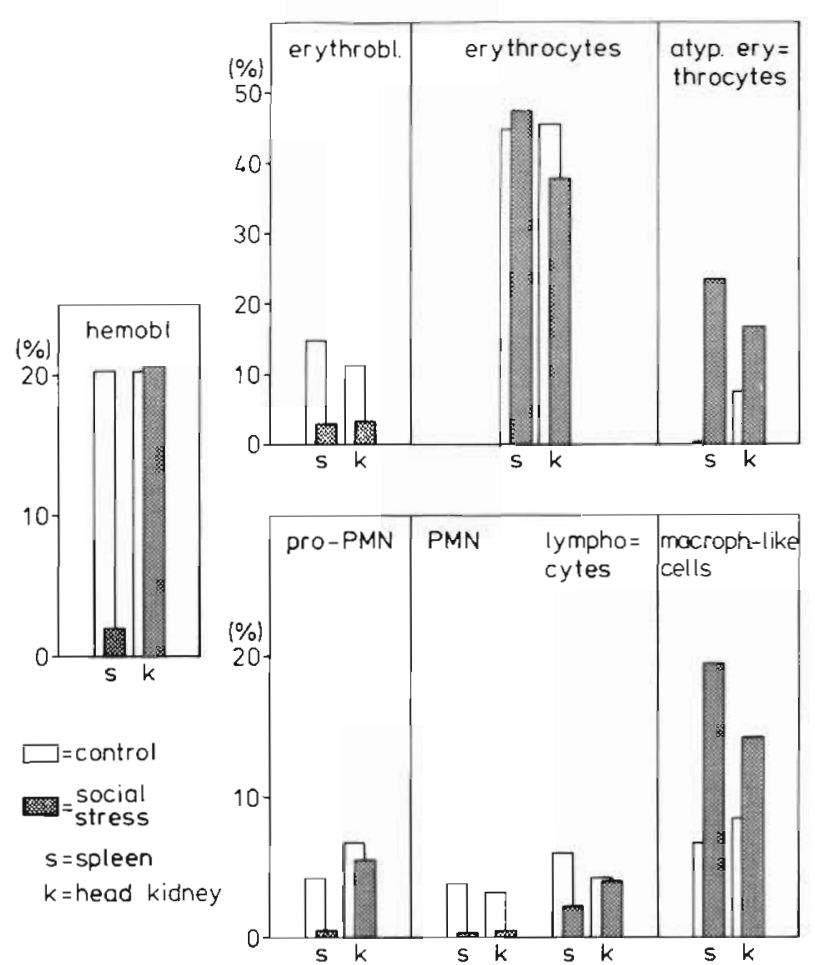

Fig. 8. Salmo gairdneri. Blood cell counts in spleen (2 left bars) and head kidney (2 right bars) tissue smears from unstressed trout (white bars) and those stressed over several days (gray bars). Each bar represents the mean of cell counts from 6 fish

does not seem to result from an expulsion of young cells into the peripheral blood; they have never been seen in blood smears of stressed fish (Klinger 1983).

It must be noted that fishes usually possess 2 morphologically distinct kinds of lymphocyte. In this paper, only the small ones have been mentioned. Their number decreases under stress. In the spleen and head kidney tissue large lymphocytes also occur, which, however, cannot be reliably distinguished from the hemoblasts. Therefore, both these cell types are considered a single group. This means that the large lymphocytes also may become less abundant under stress.

The changes in the red blood cells always result in shrinkage. Nevertheless, the cells show no signs of autolytic activity. They seem rather to be phagocytized.

The processes occurring in the hemopoietic tissues are apparently either adaptive or degenerative. The transition, particularly of neutrophilic PMN cells into macrophage-like forms, could be interpreted as a nonspecific adaptation to a stress situation. The structural and quantitative changes of these leucocytes, at least during the initial reaction phase, reflect a functional activation of the hemopoietic tissues, i.e. an enhanced phagocytotic and intracellular killing capacity. In this way, the body would be prepared for an impending danger in the form of invading pathogens. This interpretation would be in keeping with Selye's General Adaptation Syndrome. Ramos \& Smith (1978) found that after exposure to stress, C-reactive protein appears in the blood of tilapia. This reaction also occurs very quickly, and it is similarly non-specific.

The cellular alterations also give evidence that immunological functions are impaired. As in the spleen and head kidney antibodies are carried by lymphocytes, blast-like cells, and macrophages (Chiller et al. 1969), the progressive vacuolation and disintegration of these cells under stress may reflect a reduction of their defence activities. The blast stages that could make up for this deficit also undergo hypertrophy and degeneration.

Under continued stress, processes become apparent that not only indicate a maladaptation but also seem to represent an accelerated self-destruction. Ellis (1982) supposes that neutrophils of fish produce free radicals which may develop self-tissue destructive power under certain circumstances. Perhaps the increased autoagglutinating tendencies and the enhanced destruction of erythrocytes in the stressed trout indicates that the body no longer protects its own cells.

Regarding the relation between the changes observed in the hemopoietic tissues and those in the peripheral blood of stressed fish, obvious correlations are to be found. The lymphocytopenia described by numerous authors corresponds to the decrease in the number of lymphocytes found in the spleen and head kidney. The increase in the number of granulocytes in the circulating blood after stress is accompanied by a structural change in these cells: many of them are enlarged and display a foamy and vacuolated cytoplasm. Thus they resemble young stages of the macrophage-like cells that develop in the hemopoietic organs. Perhaps the more hypertrophic ones become enmeshed in the RES-net or stick in narrow capillaries. Frequently large leucocytes have been seen in the stomach and gill capillaries of stressed eels (Peters 1982, Peters \& Hong 1985).

The changes in the blood cells of stressed trout generally correspond to alterations in mammalian blood resulting from a strong stimulus. They are characterized by an increase in the abundance of neutrophilic granulocytes and an decrease in the number of lymphocytes (Dougherty 1952, Pearson et al. 1978). Mammals also react to non-specific stimuli by increases in the phagocytic capacity and mobility of the granulocytes (White \& Goldstein 1972).

Under our experimental conditions, social stress had stronger effects on the leucocytes than handling. Fishes with low rank in the hierarchy showed disturbances even when no noticeable battles took place. 
The passive threat by the partner was sufficient. Barrow (1955) discovered that fish kept in aquaria produce antibodies against trypanosomes only when their rank in the hierarchy is high. A similar kind of stress seems to occur among certain fish species when they are kept at high stocking densities. It was found that blue guramis Trichogaster trichopterus living under crowded conditions suppressed the formation of antibodies against IPN virus (Perlmutter et al. 1973).

All of these results reinforce the findings that even among fishes, psychic irritations can have serious physical consequences.

Acknowledgements. We gratefully acknowledge comments and criticisms by Dr. E. A. Ellis, Aberdeen, of the manuscript, We thank Mrs. M. Brumm and Mrs. W. Schmidt for technical help, Prof. Dr. H. Schliemann and Prof. Dr. N. Peters (Zoologisches Institut der Universität Hamburg) for their permission to use a photo- and an electronmicroscope. This work was supported by the Bundesministerium für Forschung und Technologie, Grant No. MFE 0528.

\section{LITERATURE CITED}

Anderson, D. P. (1974). Fish immunology. In: Snieszko, S. F., Axelrod, H. R. (ed.) Diseases of fishes. T. F. H. Publications, Neptune. New York, p. 1-237

Barrow, J. H. (1955). Social behavior in freshwater fish and its effect on resistance to trypanosomes. Proc. natn. Acad. Sci. U.S.A. 41: 676-679

Chiller, J. M., Hodgekins, H. O., Chambers, V. C., Weiser, R. $\mathrm{S}$. (1969). Antibody response in rainbow trout (Salmo gairdneri). I. Immunocompetent cells in the spleen and anterior kidney. J. Immun. 102: 1193-1201

Corbel, M. J. (1975). The immune response in fish: a review. J. Fish Biol. 7: 539-563

David, H. (1970). Zellschädigung und Dysfunktion. Protoplasmatologia X (1): $1-612$

Dougherty, T. F. (1952). Effect of hormones on lymphatic tissue. Physiol. Rev. 32: 379-401

Ellis, A. E. (1977). The leucocytes of fish: a review. J. Fish Biol. 11 (5): 453-492

Ellis, A. E. (1981). Stress and the modulation of defence mechanisms in fish. In: Pickering, A. D. (ed.) Stress and fish. Academic Press, London, p. 147-169

Ellis, A. E. (1982). Difference between the immune mechanisms of fish and higher vertebrates. In: Roberts, R. J. (ed.) Microbial diseases of fish. Academic Press, London, p. $1-29$

Finn, P. J., Nielson, N. O. (1971). The inflammatory response of rainbow trout. J. Fish Biol. 3: 463-478

Hong, Ly Quang (1982). Der Einfluß der Streßbelastung auf den Elektrolythaushalt und einige Organe des Europäischen Aals, Anguilla anguilla L. Diplomarbeit, Univ. Hamburg

Ingram, G. A. (1980). Substances involved in the natural resistance of fish to infection: a review. J. Fish Biol. 16 (1): $23-60$

Klinger, H. (1983). Grundlagen und Anwendung hämatologischer und morphologischer Methoden zur Diagnose von Streß in der Fischhaltung unter besonderer Berücksichtigung des Aals (Anguilla anguilla L.). Diss. Univ. Hamburg

Lehmann, J., Stürenberg, F.-J. (1975). Haematologischserologische Substratuntersuchungen an der Regenbogenforelle (Salmo gairdneri Rich.). Gewässer und Abwässer 55/56: 1-121

McLeay, D. J. (1973). Effects of cortisol and dexamethasone on the pituitary-interrenal axis and abundance of white blood cell types in juvenile Coho salmon, Oncorhynchus kisutch. Gen. Comp. Endocrinol. 21: 441-450

Pearson, C. M., Clements, P. J., Yu, D. T. Y. (1978). The effects of corticosteroids on lymphocyte functions. Eur. J. Rheumat. Inflammat. 1: 216-225

Perlmutter, A., Sarot, D. A., Yu, M., Filazzola, R. J., Seeley, R. $J$. (1973): The effect of crowding on the immune response of the blue gourami, Trichogaster trichopterus, to Infectious Pancreatic Nectosis (IPN) virus. Life sci. 13: 363-375

Peters, G. (1982). The effect of stress on the stomach of the European eel, Anguilla anguilla L. J. Fish Biol. 21: 497-512

Peters, G., Delventhal, H., Klinger, H. (1980). Physiological and morphological effects of social stress in the eel, Anguilla anguilla L. Arch. FischWiss. 30 (2/3): 157-180

Peters, G., Hong, L. Q. (1985). Gill structure and blood electrolyte levels of European eels under stress. In: Ellis, A. E. (ed.) Fish and shellfish pathology. Academic Press, London, p. 183-196

Pickford, G. E., Szivastava, A. K., Slicher, A. M., Pang, P. K. T. (1971). The stress response in the abundance of circulating leucocytes in the killifish, Fundulus heteraclitus. J. exp. Zool. 177: 109-117

Ramos, F., Smith, A. C. (1978). The C reactive protein test for the detection of early disease in fishes. Aquaculture 14 (3): 261-266

Selye, H. (1936). A syndrome produced by diverse nocuous agents. Nature, Lond. 138: 32

Selye, H. (1976). Stress in health and disease. Butterworth, Boston

Slicher, A. M., Pickford, G. E., Ball, J. N. (1962). Effect of ACTH and coldshock on white cell count of fishes. Anat. Rec. 142: 327

Snieszko, S. F. (1974). The effects of environmental stress on outbreaks of infectious diseases of fishes. J. Fish Biol. 6 (2): 197-208

Wedemeyer, G. (1970). The role of stress in disease resistance of fishes. In: Snieszko, S. F. (ed.) A symposium on diseases of fishes and shellfishes. Am. Fish Soc. Spec. Publ. 5: 30-35

Weinreb, E. C. (1958). Studies on the histology and histopathology of the rainbow trout (Salmo gairdneri irideus). I. Hematology under normal and experimental conditions of inflammation. Zoologica, N. Y. 43 (4): 145-155

White, A., Goldstein, A. L. (1972). Hormonal regulations of host immunity. In: Borek, F. (ed.) Frontiers of biology, 25, North-Holland Publ. Co., Amsterdam, p. 334-364 